\title{
Expression of Aldo-keto Reductase 1C23 in the Equine Corpus Luteum in Different Luteal Phases
}

\author{
Keisuke KOZAI 1), Takuo HOJO'1), Shota TOKUYAMA ${ }^{2)}$, Anna Z SZÓSTEK ${ }^{3)}$, \\ Masashi TAKAHASHI ${ }^{4}{ }^{5)}$, Miki SAKATANI ${ }^{4}$, Yasuo NAMBO ${ }^{6}$, , Dariusz J SKARZYNSKI ${ }^{3)}$ and \\ Kiyoshi OKUDA ${ }^{1,2)}$ \\ 1) Laboratory of Reproductive Physiology, Graduate School of Environmental and Life Science, Okayama University, \\ Okayama 700-8530, Japan \\ 2) Laboratory of Reproductive Physiology, Graduate School of Natural Science and Technology, Okayama University, \\ Okayama 700-8530, Japan \\ 3) Department of Reproductive Immunology and Pathology, Institute of Animal Reproduction and Food Research, Polish \\ Academy of Sciences, 10-747 Olsztyn, Poland \\ 4) Kyushu Okinawa Agricultural Research Center, National Agriculture and Food Research Organization (NARO), \\ Kumamoto 861-1192, Japan \\ 5) Department of Animal Science, Hokkaido University, Hokkaido 060-8589, Japan \\ 6) Equine Science Division, Hidaka Training and Research Center Japan Racing Association, Hokkaido 057-0171, Japan
}

\begin{abstract}
Regression of the corpus luteum (CL) is characterized by a decay in progesterone $\left(\mathrm{P}_{4}\right)$ production (functional luteolysis) and disappearance of luteal tissues (structural luteolysis). In mares, structural luteolysis is thought to be caused by apoptosis of luteal cells, but functional luteolysis is poorly understood. $20 \alpha$-hydroxysteroid dehydrogenase (20 $\alpha$-HSD) catabolizes $\mathrm{P}_{4}$ into its biologically inactive form, $20 \alpha$-hydroxyprogesterone (20 $\alpha$-OHP). In mares, aldo-keto reductase (AKR) $1 \mathrm{C} 23$, which is a member of the AKR superfamily, has $20 \alpha-\mathrm{HSD}$ activity. To clarify whether AKR1C23 is associated with functional luteolysis in mares, we investigated the expression of AKR1C23 in the CL in different luteal phases. The luteal $\mathrm{P}_{4}$ concentration and levels of $3 \beta$-hydroxysteroid dehydrogenase $(3 \beta$-HSD) mRNA were higher in the mid luteal phase than in the late and regressed luteal phases $(\mathrm{P}<0.05)$, but the level of $3 \beta-\mathrm{HSD}$ protein was higher in the late luteal phase than in the regressed luteal phase $(\mathrm{P}<0.05)$. The luteal $20 \alpha-\mathrm{OHP}$ concentration and the level of $A K R 1 C 23$ mRNA were higher in the late luteal phase than in the early and mid luteal phases $(\mathrm{P}<0.05)$, and the level of AKR1C23 protein was also highest in the late luteal phase. Taken together, these findings suggest that metabolism of $\mathrm{P}_{4}$ by AKR1C23 is one of the processes contributing to functional luteolysis in mares.
\end{abstract}

Key words: $20 \alpha$-hydroxysteroid dehydrogenase, Corpus luteum, Functional luteolysis, Mares, Progesterone

(J. Reprod. Dev. 60: 150-154, 2014)

T he corpus luteum (CL) is a mammalian endocrine organ that is formed in the ovary after ovulation. The CL produces progesterone $\left(\mathrm{P}_{4}\right)$, which is essential for the establishment and maintenance of pregnancy. In the absence of pregnancy, the CL regresses following the pulsatile release of uterine prostaglandin F2 $\alpha$ (PGF). Regression of the $\mathrm{CL}$ is characterized by a decay in $\mathrm{P}_{4}$ production (functional luteolysis) and the disappearance of luteal tissue (structural luteolysis) [1]. In mares, structural luteolysis has been suggested to be caused by apoptosis of luteal cells [2], while functional luteolysis is poorly understood.

$\mathrm{P}_{4}$ is catabolized into its biologically inactive form,

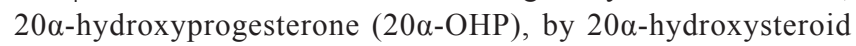
dehydrogenase (20 $\alpha$-HSD). In rodents, ovarian $20 \alpha$-HSD plays a role in functional luteolysis at term of pseudopregnancy as well as

Received: November 6, 2013

Accepted: December 27, 2013

Published online in J-STAGE: February 4, 2014

(C)2014 by the Society for Reproduction and Development

Correspondence: K Okuda (e-mail: kokuda@cc.okayama-u.ac.jp) during the estrous cycle $[3,4]$. Recently, it has also been demonstrated in the bovine CL that $20 \alpha$-HSD is expressed throughout the estrous cycle and that $20 \alpha$-HSD expression is remarkably higher in the late stage than in the other stages of the estrous cycle [5].

Aldo-keto reductases (AKRs) are multifunctional enzymes that act on a wide range of substrates including steroid hormones [6]. In mares, AKR1C23 has $20 \alpha$-HSD activity and converts $\mathrm{P}_{4}$ to $20 \alpha-\mathrm{OHP}$ [7]. Although it is reported that AKR1C23 is expressed in the equine CL [7], the role of AKR1C23 in the equine CL remains unclear. In the present study, to clarify the possible mechanism of functional luteolysis in mares, we investigated the $20 \alpha-\mathrm{OHP}$ concentrations and expression of AKR1C23 in the equine $C L$ in the different luteal phases.

\section{Materials and Methods}

\section{Collection of equine CLs}

Fifty-eight Anglo-Norman mares of various ages and weighing approximately $1,000 \mathrm{~kg}$, which were imported from Canada and then fattened at a ranch adjacent to an abattoir $\left(\sim \mathrm{N} 32^{\circ}\right)$ in Kumamoto, Japan, for at least two years before exsanguination, were utilized in 
the present study. Fifty-eight ovaries containing a CL were collected from randomly designated cyclic nonpregnant mares at the abattoir in accordance with protocols approved by the local institutional animal care and use committee from April until the end of August. Mares possessing ovaries with a macroscopic abnormality including anovulatory hemorrhagic follicles were eliminated. After midsagittal sectioning, the CLs were classified as being in the early, mid, late or regressed luteal phase $(n=3-8 /$ phase $)$ by macroscopic observation of the CLs and follicles (Table 1) as described previously [8, 9]. Following determination of the phases, CL tissues were immediately separated from the ovaries, rinsed with cold sterile saline, frozen rapidly in liquid nitrogen and then stored at $-80 \mathrm{C}$ until being processed for $\mathrm{P}_{4}, 20 \alpha-\mathrm{OHP}, \mathrm{RNA}$ and protein extraction.

\section{$P_{4}$ and $20 \alpha-O H P$ extraction}

$\mathrm{P}_{4}$ and $20 \alpha-\mathrm{OHP}$ were extracted from luteal tissues as described previously [10]. Briefly, $2 \mathrm{ml}$ of ethanol was added to the minced luteal tissue samples (approximately $0.2 \mathrm{~g}$ ). The tissues were then homogenized 5 times for $10 \mathrm{sec}$ on ice by a tissue homogenizer (Physcotron; NITI-ON, Chiba, Japan; NS-50) and 3 times for $1 \mathrm{~min}$ on ice by an ultrasonic homogenizer (VCX400 Vibra-Cell; Sonics \& Materials, Newtown, CT, USA). After centrifugation (1,700 rpm for $30 \mathrm{~min}$ at $4 \mathrm{C}$ ), the supernatant was evaporated in a vacuum oven at $50 \mathrm{C}$, and the residue was dissolved in $2 \mathrm{ml}$ of enzyme immunoassay (EIA) buffer (7.12 $\mathrm{g} \mathrm{Na}_{2} \mathrm{HPO}_{4}-2 \mathrm{H}_{2} \mathrm{O}, 8.5 \mathrm{~g} \mathrm{NaCl}$ in 1,000 ml ultrapure water, $\mathrm{pH} 7.2$ ).

\section{$P_{4}$ and $20 \alpha-O H P$ determination}

The concentrations of $\mathrm{P}_{4}$ in the tissue extracts were determined directly by EIA as described previously [11]. The $\mathrm{P}_{4}$ standard curve ranged from 0.391 to $100 \mathrm{ng} / \mathrm{ml}$, and the ED50 of the assay was $2.0 \mathrm{ng} / \mathrm{ml}$. The intra- and interassay coefficients of variation were on average 5.4 and $7.0 \%$, respectively. The cross-reactivity of the antibody was $100 \%$ for $\mathrm{P}_{4}$ and $0.03 \%$ for $20 \alpha-\mathrm{OHP}$.

The concentrations of $20 \alpha-\mathrm{OHP}$ in the tissue extracts were determined directly by EIA. The $20 \alpha$-OHP EIA was based on the EIA for $\mathrm{P}_{4}$ with some modifications. Standards or samples $(20 \mu \mathrm{l})$ were incubated with $50 \mu$ polyclonal antibody (raised in a rabbit against $20 \alpha-\mathrm{OH}-\mathrm{Progesterone-3-CMO-BSA}$; Cosmo Bio, Tokyo, Japan) solution $(1: 800,000)$ and $50 \mu 120 \alpha-O H-P r o g e s t e r o n e-3-C M O-H R P$ (1:400,000; Cosmo Bio) for $16 \mathrm{~h}$ at $4 \mathrm{C}$. The standard curve ranged from 0.0976 to $50 \mathrm{ng} / \mathrm{ml}$, and the ED50 of the assay was $2.5 \mathrm{ng} / \mathrm{ml}$. The intra- and interassay coefficients of variation were on average 6.8 and $8.6 \%$, respectively. The cross-reactivity of the antibody was $100 \%$ for $20 \alpha$-OHP, $1.22 \%$ for $\mathrm{P}_{4}, 0.99 \%$ for pregnenolone and $0.35 \%$ for testosterone.

\section{RNA isolation and $c D N A$ synthesis}

Total RNA was prepared from luteal tissues using TRIzol Reagent according to the manufacturer's directions (no. 15596-026; Invitrogen, Carlsbad, CA, USA). Total RNA ( $1 \mu \mathrm{g})$ was reverse transcribed using a ThermoScript RT-PCR System (no. 11146-016; Invitrogen).

\section{Real-time PCR}

Gene expression was determined by real-time PCR using a MyiQ system (no. 170-9740, Bio-Rad Laboratories, Melville, NY, USA) and SYBR ${ }^{\circledR}$ Premix Ex Taq ${ }^{\mathrm{TM}}$ II (RR081B, TaKaRa, Shiga, Japan) starting with $2 \mathrm{ng}$ of reverse-transcribed total RNA as described previously [12]. Briefly, for quantification of the mRNA expression levels, the primer length (20-25 bp) and GC contents of each primer (50-60\%) were synthesized (Table 2) and were chosen using an online software package [13]. To determine the most stable internal control gene under our experimental conditions, three potential housekeeping genes were initially considered ( $\beta 2$-microglobulin (B2M), glyceraldehyde-3-phosphate dehydrogenase (GAPDH) and $\beta$-actin), and geNorm analysis was performed using the geNorm software (version 3.5). The $\mathrm{M}$ values of $\mathrm{B} 2 \mathrm{M}$, GAPDH and $\beta$-actin were $0.784,0.505$ and 0.501 , respectively. Therefore, $\beta$-actin was identified as the most stable gene. The primers for $3 \beta-H S D, A K R 1 C 23$ and $\beta$-actin generated specific 132-bp, 148-bp and 113-bp products, respectively. Each PCR yielded only a single amplification product. PCR was performed under the following conditions: $95 \mathrm{C}$ for 3 min, followed by 45 cycles of $94 \mathrm{C}$ for $15 \mathrm{sec}, 55 \mathrm{C}$ for $20 \mathrm{sec}$ and $72 \mathrm{C}$ for $15 \mathrm{sec}$. Use of $\mathrm{SYBR}^{\circledR}$ Premix Ex Taq ${ }^{\mathrm{TM}}$ II at elevated temperatures resulted in reliable and sensitive quantification of the RT-PCR products with high linearity (Pearson correlation coefficient $r>0.99$ ). To correct for differences in RNA quality and quantity between samples, the expression levels of target gene mRNA were normalized by dividing the quantity of the target gene by the quantity of $\beta$-actin in each sample.

\section{Western blot analysis}

Each protein in the luteal tissues was assessed by Western blot analysis. The luteal tissues were homogenized on ice in homogenization buffer ( $25 \mathrm{mM}$ Tris-HCl, $300 \mathrm{mM}$ sucrose, 2 mM EDTA, Complete [protease inhibitor cocktail; no. 11697498 001; Roche Diagnostics, Mannheim, Germany], pH 7.4) by the tissue homogenizer, followed by filtration with a metal wire mesh $(150 \mu \mathrm{m})$. For protein analysis, tissue homogenates were centrifuged at $600 \times g$ for $10 \mathrm{~min}$ at $4 \mathrm{C}$. The supernatants were then centrifuged at $9,000 \times g$ for $30 \mathrm{~min}$ at 4 $\mathrm{C}$, and the resulting supernatants were used as cytoplasmic fraction. Protein concentrations were determined by the BCA method [14] using BSA as a standard.

The protein samples ( $50 \mu \mathrm{g}$ protein) were then solubilized in SDS gel-loading buffer (50 mM Tris-HCl, 2\% SDS [no. 31607-94; Nacalai Tesque, Kyoto, Japan], 10\% glycerol, 1\% $\beta$-mercaptoethanol [no. 137-06862; Wako Pure Chemical Industries, Osaka, Japan], pH 6.8), heated at $95 \mathrm{C}$ for $10 \mathrm{~min}$ and subjected to $15 \%$ SDS-PAGE for $1 \mathrm{~h}$ at $250 \mathrm{~V}$. Separated proteins were electrophoretically transferred to polyvinylidene difluoride membranes (RPN303F; GE Healthcare, Milwaukee, WI, USA) for $40 \mathrm{~min}$ at $200 \mathrm{~mA}$ using a Trans-Blot ${ }^{\circledR}$ SD Semi-Dry Electrophoretic Transfer Cell (no. 170-3940, Bio-Rad Laboratories). The membranes were incubated in blocking buffer (5\% nonfat dry milk in TBS $[25 \mathrm{mM}$ Tris- $\mathrm{HCl}, 137 \mathrm{mM} \mathrm{NaCl}, \mathrm{pH}$ 7.5] with $0.1 \%$ Tween 20 [TBST]) for $1 \mathrm{~h}$ at room temperature and then incubated separately with specific primary antibodies to $3 \beta$-HSD (40 kDa; 1:6,000; ab75710; Abcam plc., Cambridge, UK), AKR1C1 (37 kDa; 1:5,000; LS-B6269; LifeSpan BioSciences, Seattle, WA, USA) and $\beta$-actin (42 kDa; 1:4,000; A2228; Sigma-Aldrich, St. Louis, MO, USA) in TBST overnight at $4 \mathrm{C}$. After primary antibody incubation, the membranes were washed in TBST for $10 \mathrm{~min} 3$ times at room temperature. After washing, the membranes were incubated 
Table 1. Macromorphological criteria of the ovary for classifying the luteal phase in mares

\begin{tabular}{|c|c|c|c|c|c|}
\hline Tissue & Criteria & $\begin{array}{c}\text { Early luteal phase } \\
\text { (Corpus hemorrhagicum) }\end{array}$ & Mid luteal phase & Late luteal phase & Regressed luteal phase \\
\hline \multirow[t]{2}{*}{$\overline{C L}$} & Appearance & $\begin{array}{l}\text { A large central cavity is } \\
\text { filled with blood clot }\end{array}$ & $\begin{array}{l}\text { CL is irregular, mushroom } \\
\text { shaped or gourd shaped }\end{array}$ & $\begin{array}{l}\text { CL is irregular, mushroom } \\
\text { shaped or gourd shaped }\end{array}$ & $\begin{array}{c}\text { CL has a small and oblong } \\
\text { structure }\end{array}$ \\
\hline & Color & Dark red & Flesh colored & Buff colored & Straw colored \\
\hline Follicle & $\begin{array}{l}\text { Diameter of the } \\
\text { largest follicle }(\mathrm{mm})\end{array}$ & & $15-20$ & $30-35$ & $>35$ \\
\hline
\end{tabular}

Table 2. Primers used in real-time PCR

\begin{tabular}{|c|c|c|c|c|}
\hline Gene & Primer & Sequence & Accession No. & Product size \\
\hline \multirow[t]{2}{*}{$3 \beta-H S D$} & Forward & 5'-TGGCATCCTGACACACAACT-3' & \multirow{2}{*}{ D89666 } & \multirow{2}{*}{132 bp } \\
\hline & Reverse & 5'-AACTGTCCTTGGATGCTTGG-3' & & \\
\hline \multirow[t]{2}{*}{$A K R 1 C 23$} & Forward & 5'-CATGAAAGTCCTAGATGGCCTAAAC-3' & \multirow{2}{*}{ AY955082 } & \multirow{2}{*}{$148 \mathrm{bp}$} \\
\hline & Reverse & 5'-CACTATCCACACACAGGGCTTC-3' & & \\
\hline \multirow[t]{2}{*}{$\beta$-actin } & Forward & 5'-ATGGGCCAGAAGGACTCATA-3' & \multirow{2}{*}{ NM_001081838 } & \multirow{2}{*}{$113 \mathrm{bp}$} \\
\hline & Reverse & 5'-TTCTCCATGTCGTCCCAGTT-3' & & \\
\hline
\end{tabular}

with secondary antibody (anti-mouse, HRP-linked whole antibody produced in sheep [NA931; Amersham Biosciences, San Francisco, CA, USA]; 1: 6,000 for 3 $\beta$-HSD, 1: 10,000 for AKR1C1, 1: 40,000 for $\beta$-actin) in TBST for $1 \mathrm{~h}$ at room temperature, washed in TBST for 10 min 3 times at room temperature and then incubated with Immobilon Western Chemiluminescent HRP Substrate (WBKLS0500; Merck KGaA, Darmstadt, Germany). Images were captured using a ChemiDoc ${ }^{\mathrm{TM}}$ XRS + System (\#170-8265; Bio-Rad Laboratories). The intensity of the immunological reaction was estimated by measuring the optical density in the defined area by computerized densitometry using NIH Image (National Institutes of Health, Bethesda, MD, USA).

\section{Statistical analysis}

The results are expressed as mean \pm SEM values obtained from 3-8 luteal tissues/phase. The statistical significance of differences in luteal $\mathrm{P}_{4}$ and $20 \alpha-\mathrm{OHP}$ concentrations, the levels of $3 \beta-H S D$

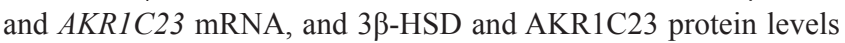
was analyzed by a one-way analysis of variance (ANOVA). The comparisons between phases were performed using the Tukey-Kramer multiple comparison test. P values $<0.05$ were considered significant.

\section{Results}

\section{Luteal $P_{4}$ and $20 \alpha$-OHP concentration in the different luteal phases}

The luteal $\mathrm{P}_{4}$ concentration was higher in the mid luteal phase than in the late and regressed luteal phases (Fig. 1a: $\mathrm{P}<0.05)$. The luteal $20 \alpha-O H P$ concentration was higher in the late luteal phase than in any other luteal phases (Fig. $1 \mathrm{~b}$ : $\mathrm{P}<0.05$ ).

\section{Expressions of $3 \beta-H S D m R N A$ and protein in the equine $C L$ in the different luteal phases}

Specific transcripts for $3 \beta$-HSD were detected in the equine CL throughout the luteal phase. The level of $3 \beta-H S D$ mRNA was higher in the early and mid luteal phases than in the late and regressed luteal phases (Fig. 2a: $\mathrm{P}<0.05$ ). $3 \beta$-HSD protein was expressed in the equine CL throughout the luteal phase. The level of $3 \beta-H S D$ protein was higher in the late luteal phase than in the regressed luteal phase (Fig. 2b: $\mathrm{P}<0.05$ ).

Expressions of $A K R 1 C 23 m R N A$ and protein in the equine $C L$ in the different luteal phases

Specific transcripts for AKR1C23 were detected in the equine CL throughout the luteal phase. The level of AKR1C23 mRNA was higher in the late luteal phase than in the early and mid luteal phases (Fig. 3a: $\mathrm{P}<0.05$ ). AKR1C23 protein was expressed in the equine $\mathrm{CL}$ throughout the luteal phase. The level of AKR1C23 protein was higher in the late luteal phase than in the early luteal phase (Fig. 3b: $\mathrm{P}<0.05)$.

\section{Discussion}

In the present study, $\mathrm{P}_{4}$ concentrations in the luteal tissues were high in the mid luteal phase and low in the late and regressed luteal phases. This result is consistent with previous reports that showed changes in circulating $\mathrm{P}_{4}$ concentration throughout the luteal phase in mares $[15,16]$, indicating that functional luteolysis occurs in the late luteal phase. As in the case of the $\mathrm{P}_{4}$ concentrations in the luteal tissues, the mRNA expression of $3 \beta-H S D$, which converts pregnenolone into $\mathrm{P}_{4}$, was higher in the early and mid luteal phases than in the late and regressed luteal phases. However, unexpectedly, the level of $3 \beta-H S D$ protein was highest in the late luteal phase. In cattle $[17,18]$ and sheep $[19,20]$, the level of mRNA for $3 \beta$-HSD decreased in parallel with circulating $\mathrm{P}_{4}$ concentrations during PGF-induced luteolysis, but $3 \beta$-HSD protein expression or activity in the CL did not change. Based on the above findings, $3 \beta-\mathrm{HSD}$ activity in the CL may not play a role in functional luteolysis in mares.

The 20 $\alpha$-OHP concentrations in the luteal tissues were higher in 
(a)

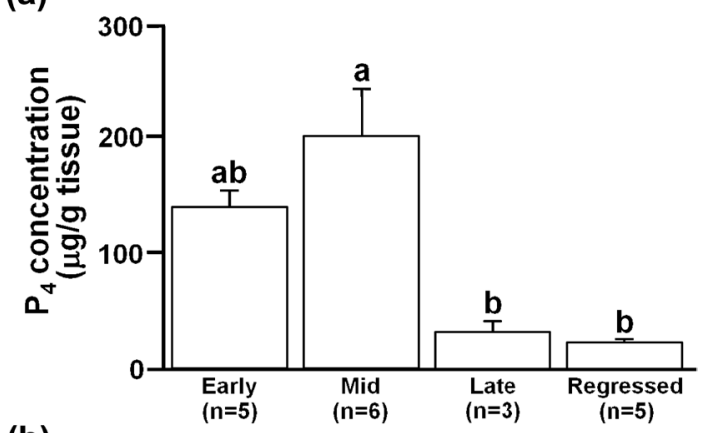

(b)

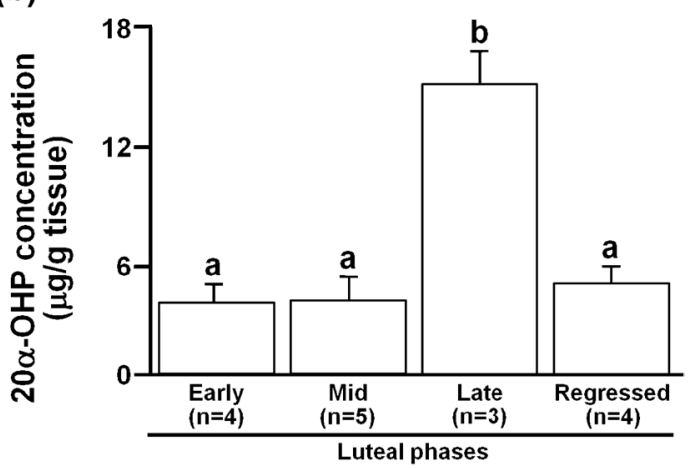

Fig. 1. Luteal $\mathrm{P}_{4}$ (a) and $20 \alpha-\mathrm{OHP}$ (b) concentrations in the different luteal phases. All experimental data are shown as means \pm SEM. Different letters indicate significant differences $(\mathrm{P}<0.05)$ as determined by ANOVA followed by the Tukey-Kramer multiple comparison test.

the late luteal phase than in any other luteal phases. This finding strongly suggests that $\mathrm{P}_{4}$ is converted into $20 \alpha$-OHP in the late luteal tissues. In rodents, $20 \alpha-\mathrm{HSD}$ expressed in luteal cells catabolizes $\mathrm{P}_{4}$

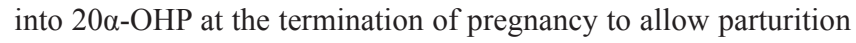
to occur [21]. In mares, AKR1C23 has $20 \alpha$-HSD activity; i.e., it converts $\mathrm{P}_{4}$ into 20 $\alpha$-OHP [7]. In the present study, the mRNA and protein expressions of AKR1C23 were highest in the late luteal phase when the 20 $\alpha$-OHP concentration in the luteal tissues reached a peak. These results are consistent with previous observations in the bovine CL [5]. Together, our findings suggest that AKR1C23 converts $P_{4}$ into $20 \alpha$-OHP in the late luteal phase, resulting in a decrease in the luteal $\mathrm{P}_{4}$ concentration (Fig. 1a). In mares, PGF secreted from the uterus in the late luteal phase induces luteolysis, i.e., a decrease in circulating $\mathrm{P}_{4}$ concentration [22]. In addition, Fas ligand (FASL) expressed in the late $\mathrm{CL}$ reduces $\mathrm{P}_{4}$ production and stimulates PGF production by equine luteal cells [23]. In rodents, PGF has been demonstrated to induce $20 \alpha$-HSD expression in the CL, which is accompanied by a significant reduction in the circulating levels of $\mathrm{P}_{4}$ and a rise in the levels of 20 $\alpha$-OHP [21]. Based on the above findings, AKR1C23 expression in the equine CL may be induced by PGF and FASL, leading to functional luteolysis. Further study is needed to clarify the mechanism of the regulation of AKR1C23 expression in the equine CL.

The overall findings in the present study strongly suggest that (a)

(b)
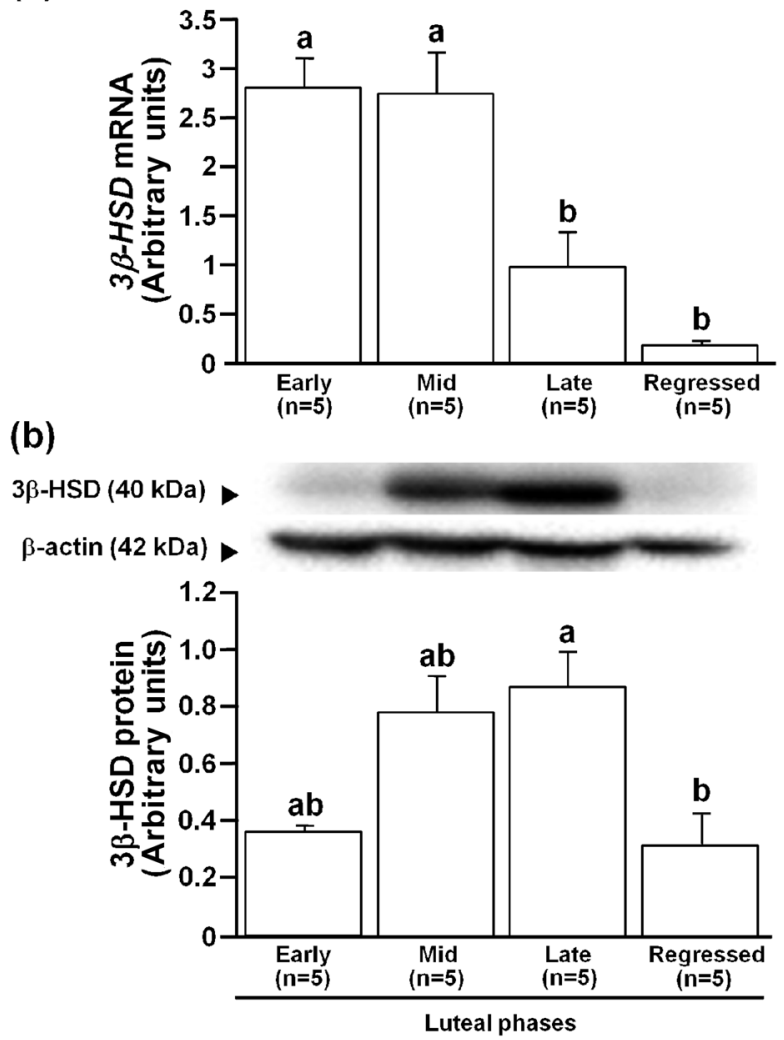

Fig. 2. Expressions of $3 \beta$-HSD mRNA (a) and protein (b) in the equine CL in the different luteal phases. All experimental data are shown as means \pm SEM. Different letters indicate significant differences $(\mathrm{P}<0.05)$ as determined by ANOVA followed by the Tukey-Kramer multiple comparison test.

conversion of $\mathrm{P}_{4}$ into $20 \alpha$-OHP by AKR1C23 is one of the processes contributing to functional luteolysis in mares.

\section{Acknowledgments}

This study was supported by the Japanese-Polish Joint Research Project under an agreement between the Japan Society for the Promotion of Science and Polish Academy of Sciences and was supported in part by the Equine Research Institute, Japan Racing Association.

\section{References}

1. McCracken JA, Custer EE, Lamsa JC. Luteolysis: a neuroendocrine-mediated event. Physiol Rev 1999; 79: 263-323. [Medline]

2. Al-Zi'abi MO, Fraser HM, Watson ED. Cell death during natural and induced luteal regression in mares. Reproduction 2002; 123: 67-77. [Medline] [CrossRef]

3. Ishida M, Choi JH, Hirabayashi K, Matsuwaki T, Suzuki M, Yamanouchi K, Horai R, Sudo K, Iwakura Y, Nishihara M. Reproductive phenotypes in mice with targeted disruption of the $20 \alpha$-hydroxysteroid dehydrogenase gene. J Reprod Dev 2007; 53: 499-508. [Medline] [CrossRef]

4. Matsuda J, Noda K, Shiota K, Takahashi M. Participation of ovarian 20 alphahydroxysteroid dehydrogenase in luteotrophic and luteolytic processes during rat pseudo- 
(a)
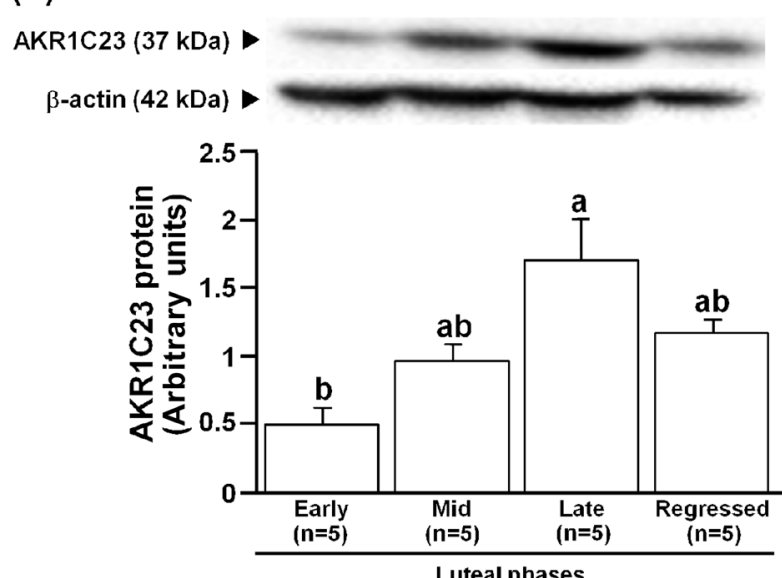

Fig. 3. Expressions of AKR1C23 mRNA (a) and protein (b) in the equine $\mathrm{CL}$ in the different luteal phases. All experimental data are shown as means \pm SEM. Different letters indicate significant differences $(\mathrm{P}<0.05)$ as determined by ANOVA followed by the Tukey-Kramer multiple comparison test.

pregnancy. J Reprod Fertil 1990; 88: 467-474. [Medline] [CrossRef]

5. Naidansuren P, Park CW, Kim SH, Nanjidsuren T, Park JJ, Yun SJ, Sim BW, Hwang S, Kang MH, Ryu BY, Hwang SY, Yoon JT, Yamanouchi K, Min KS. Molecular characterization of bovine placental and ovarian 20a-hydroxysteroid dehydrogenase. Reproduction 2011; 142: 723-731. [Medline] [CrossRef]

6. Jez JM, Bennett MJ, Schlegel BP, Lewis M, Penning TM. Comparative anatomy of the aldo-keto reductase superfamily. Biochem $J$ 1997; 326: 625-636. [Medline]
7. Brown KA, Boerboom D, Bouchard N, Doré M, Lussier JG, Sirois J. Human chorionic gonadotropin-dependent induction of an equine aldo-keto reductase (AKR1C23) with 20a-hydroxysteroid dehydrogenase activity during follicular luteinization in vivo. J Mol Endocrinol 2006; 36: 449-461. [Medline] [CrossRef]

8. Ginther OJ. Characteristics of the ovulatory season. In: Reproductive Biology of the Mare: Basic and Applied Aspects. $2^{\text {nd }}$ ed. Wisconsin: Equiservices; 1992: 173-232.

9. Ferreira-Dias G, Bravo PP, Mateus L, Redmer DA, Medeiros JA. Microvascularization and angiogenic activity of equine corpora lutea throughout the estrous cycle. Domest Anim Endocrinol 2006; 30: 247-259. [Medline] [CrossRef]

10. Wijayagunawardane MPB, Miyamoto A, Cerbito WA, Acosta TJ, Takagi M, Sato K. Local distributions of oviductal estradiol, progesterone, prostaglandins, oxytocin and endothelin-1 in the cyclic cow. Theriogenology 1998; 49: 607-618. [Medline] [CrossRef]

11. Okuda K, Uenoyama Y, Fujita Y, Iga K, Sakamoto K, Kimura T. Functional oxytocin receptors in bovine granulosa cells. Biol Reprod 1997; 56: 625-631. [Medline] [CrossRef]

12. Sakumoto R, Komatsu T, Kasuya E, Saito T, Okuda K. Expression of mRNAs for interleukin-4, interleukin-6 and their receptors in porcine corpus luteum during the estrous cycle. Domest Anim Endocrinol 2006; 31: 246-257. [Medline] [CrossRef]

13. Rozen S, Skaletsky H. Primer 3 on the WWW for general users and for biologist programmers. Methods Mol Biol 2000; 132: 365-386. [Medline]

14. Osnes T, Sandstad O, Skar V, Osnes M, Kierulf P. Total protein in common duct bile measured by acetonitrile precipitation and a micro bicinchoninic acid (BCA) method. Scand J Clin Lab Invest 1993; 53: 757-763. [Medline] [CrossRef]

15. Ginther OJ, Gastal EL, Gastal MO, Beg MA. Regulation of circulating gonadotropins by the negative effects of ovarian hormones in mares. Biol Reprod 2005; 73: 315-323. [Medline] [CrossRef]

16. Slough TL, Rispoli LA, Carnevale EM, Niswender GD, Bruemmer JE. Temporal gene expression in equine corpora lutea based on serial biopsies in vivo. J Anim Sci 2011; 89: 389-396. [Medline] [CrossRef]

17. Tian XC, Berndtson AK, Fortune JE. Changes in levels of messenger ribonucleic acid for cytochrome P450 side-chain cleavage and 3 beta-hydroxysteroid dehydrogenase during prostaglandin F2 alpha-induced luteolysis in cattle. Biol Reprod 1994; 50: 349-356. [Medline] [CrossRef]

18. Rodgers RJ, Vella CA, Young FM, Tian XC, Fortune JE. Concentrations of cytochrome P450 cholesterol side-chain cleavage enzyme and 3 beta-hydroxysteroid dehydrogenase during prostaglandin F2 alpha-induced luteal regression in cattle. Reprod Fertil Dev 1995; 7: 1213-1216. [Medline] [CrossRef]

19. Hawkins DE, Belfiore CJ, Kile JP, Niswender GD. Regulation of messenger ribonucleic acid encoding 3 beta-hydroxysteroid dehydrogenase/delta 5-delta 4 isomerase in the ovine corpus luteum. Biol Reprod 1993; 48: 1185-1190. [Medline] [CrossRef]

20. Juengel JL, Meberg BM, McIntush EW, Smith MF, Niswender GD. Concentration of mRNA encoding 3 beta-hydroxysteroid dehydrogenase/delta 5, delta 4 isomerase ( 3 betaHSD) and 3 beta-HSD enzyme activity following treatment of ewes with prostaglandin F2 alpha. Endocrine 1998; 8: 45-50. [Medline] [CrossRef]

21. Stocco CO, Zhong L, Sugimoto Y, Ichikawa A, Lau LF, Gibori G. Prostaglandin F2alpha-induced expression of 20alpha-hydroxysteroid dehydrogenase involves the transcription factor NUR77. J Biol Chem 2000; 275: 37202-37211. [Medline] [CrossRef]

22. Ginther OJ. Endocrinology of the ovulatory season. In: Reproductive Biology of the Mare: Basic and Applied Aspects. $2^{\text {nd }}$ ed. Wisconsin: Equiservices; 1992: 233-290.

23. Galvao AM, Ramilo DW, Skarzynski DJ, Lukasik K, Tramontano A, Mollo A, Mateus LM, Ferreira-Dias GM. Is FAS/Fas ligand system involved in equine corpus luteum functional regression? Biol Reprod 2010; 83: 901-908. [Medline] [CrossRef] 